UDC 621.3

\title{
HINF ROBUST CONTROL OF PERMANENT-MAGNET SYNCHRONOUS MOTORS: STABILITY AND PERFORMANCE
}

\author{
Ye. S. Rudnev, D. I. Morozov, V. Yu. Gritsyuk \\ Volodymyr Dahl East Ukrainian National University
}

\begin{abstract}
The engineering methodology for the synthesis of a robust AC electric drive control system based on a synchronous electric motor with excitation from permanent magnets with a $H_{I N F}$-suboptimal speed controller operating in conditions of incomplete information about the plant and taking into account its structural uncertainties is considered.
\end{abstract}

Key words: synchronous electric drive, robust control, uncertainty, sensitivity, simulation.

\section{Introduction}

One of the main problems of modern control theory is the management of dynamic plants in uncertainty conditions. Uncertainty is caused by the lack of complete information regarding the parameters or characteristics of the control plant, in addition, the mathematical model of the control plant itself, obtained analytically or as a result of identification, differs from the actual technical system.

In recent decades, an approach has evolved when, in the presence of uncertainty, the task of managing not a single plant, but a family of plants belonging to a given set arises. Compared with the algorithms of classical control theory, it is necessary to ensure the stability of a closed system not only for a nominal plant, but also for any plant from a given class of uncertainty - this is the task of synthesizing robust control ( $H_{\infty}$-theory).

The interest in the synthesis of robust regulators is associated with the need to reduce the required amount of a priori information about control plants, the desire for universality of control systems and reduce the cost of their adjustment. It should be recognized that, despite serious theoretical achievements [1-3], including in the field of automated electric drive, $H_{\infty}$-optimization methods are not included in the daily domestic and foreign practice. This is due to the dominance in the market of complete electric drives with "classical" control algorithms.

The goal of the work is efficient algorithms for controlling the speed of synchronous electric motors with permanent magnets (SMPM) has developed, providing an improvement in their quality in the sense of low sensitivity to the values of changing and predetermined parameters.

(C) Rudnev Ye. S., Morozov D. I., Gritsyuk V. Yu., 2019

\section{The Material Presentation and its Results}

The mathematical model of the SMPM is given in a number of papers [4-6]. The linearized mathematical model of SMPM as a control plant, necessary for the synthesis, is given by the authors in [7]. Transfer function in relation to the control action [7]:

$$
W_{\omega, U_{l q}}(p)=\frac{\left(Z_{p} \Psi_{l d 0}\right)^{-1}}{\left(T_{e l} T_{m l} p^{2}+T_{m l} p+1\right)},
$$

where $Z_{p}$ - number of poles; $\Psi_{l d 0}$ - flux linkage $d$-axis; $T_{e l}=T_{11}=\frac{L_{1}}{R_{1}} \quad-\quad$ electromagnetic time constant; $T_{m l}=\frac{2 J R_{l}}{m_{l} Z_{p}^{2} \Psi_{B} \Psi_{l q 0}}-$ electromechanical time constant.

Analysis of the transfer function (1) shows that the dynamic characteristics of a synchronous motor operating in the mode of a valve motor (brushless DC motor) are similar to those of a conventional DC motor. The structure composed on the basis of the complete linearized description of the SMPM [7] corresponds to the structure of a DC motor description with independent excitation (Fig. 1). The speed of a synchronous motor in this mode is proportional to the voltage applied to the stator windings by the frequency converter.

As an plant for further research, an electric drive with a SINAMICS frequency converter and a synchronous servomotor with excitation from permanent magnets of the 1FT6044-1AF71 type with such passport data was adopted: $U_{I N}=340 \mathrm{~V}$, $n_{N}=3000 \mathrm{rpm}, \quad Z_{p}=6, \quad I_{I N}=4,9 \mathrm{~A}, \quad J_{M}=16,3 \cdot 10$ ${ }^{4} \mathrm{~kg} \cdot \mathrm{m}^{2}, K_{t}=1,57 \mathrm{~Wb}, R_{\mathrm{s}}=1,4 \mathrm{ohm}, L_{d}=13,5 \mathrm{mH}$.

Using the designations of the parameters adopted in the above descriptions, we obtain the following values: $R_{l}=R_{s}, L_{l}=L_{d}, \Psi_{\mathrm{B}}=0,174 \mathrm{~Wb}$, $T_{11}=L_{l} / R_{l}, T_{1 l}=T_{e l}=9,64 \mathrm{~ms}, J=1,2 J_{d}, T_{m l}=$ $1,66 \mathrm{~ms}$. 


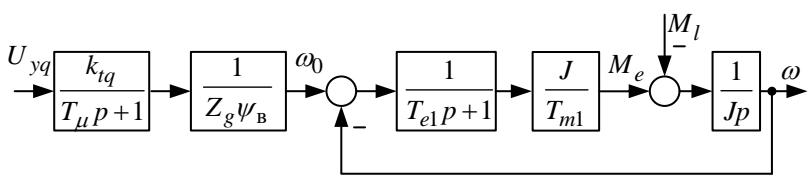

Fig. 1. Block diagram of the SMPM linearized description taking into account the inertia of the frequency converter

We suppose that the inductance of the stator winding $L_{l}$ varies in the range of $\pm 20 \%$, the active resistance of the stator winding $R_{l}$ in the range of \pm $30 \%$, and the moment of inertia $J$, reduced to the motor shaft - in the range of $\pm 40 \%$ of nominal values. The gear ratio, the time constant of the frequency converter, the flux linkage created by the permanent magnets on the rotor of the machine $\Psi_{B}$ are considered to be constant values.

A description of the above uncertainties, which are either not exactly known or are changing during the operation of the drive, presented as a linear fractional conversion (LFC); The definition of the system input/output dynamics in the matrix representation, taking into account the uncertainties like $G(s)$ - matrix of transfer function (TFM), as well as the sequence of transformation of the control plant structural schemes with uncertain parameters are considered by the authors in $[6,8]$.

In Fig. 2 shows the logarithmic frequency characteristics (LAFC and LFFC) of the perturbed (indefinite) open-loop system, which were obtained for different values of perturbation parameters $\delta_{L}, \delta_{R}$, $\delta_{J}, 3$ values are selected for each perturbation, in accordance with the created TFM of an open-loop system $[6,8]$.

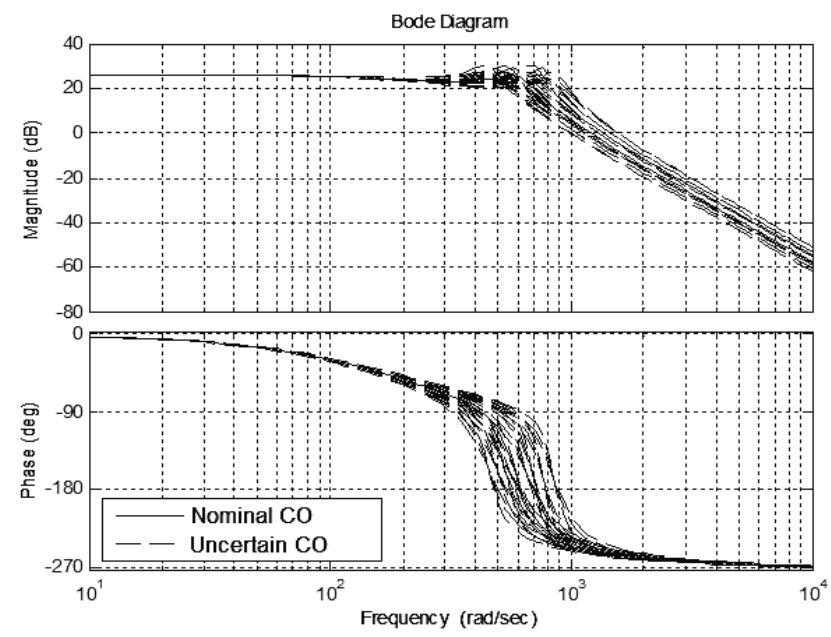

Fig. 2. LAFC and LFFC group of a perturbed system within $-1 \leq \delta_{L}, \delta_{R}, \delta_{J} \leq 1$

In $H_{\infty}$-theory by J. Doyle et al. it was proved that the standard $H_{\infty}$-control problem (which is often called the problem of minimizing the output energy) can be decoupled by solving two Riccati algebraic equations [1] and is associated with the structural diagram presented in Fig. 3.

In Fig. 3 adopted the following notation: $w(t)-$ vector external effects (perturbing and setting); $y(t)-$ vector of the measured output, used to improve the quality of the work of the ACS (a vector that closes through the feedback controller); $u(t)$ - output vector of the regulator (vector of control actions); $z(t)$ - the error vector used to control the quality of ACS (a vector that must be made minimal in a certain sense).

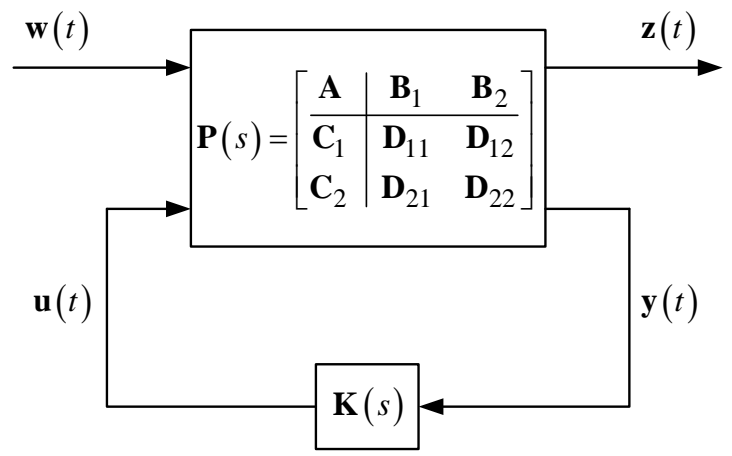

Fig. 3. Block diagram of the synthesized system (standard $\mathrm{H}_{\infty}$-control problem)

The matrix of transfer functions $P(s)$ represents not only the plant itself which must be controlled, but also the so-called. weight functions that are used to ensure the desired quality. Such an plant $P(s)$ is called a generalized (extended) plant, the block diagram of which is shown in Fig. 4.

In Fig. $4 G(s)$ - TFM of the control plant; $K(s)-$ robust regulator; $P(\mathrm{~s})-$ TFM of the generalized plant taking into account the weight functions; $W_{S}(\mathrm{~s}), W_{R}(s)$ и $W_{T}(s)$ - frequency dependent weight functions.



Fig. 4. Block diagram of a generalized plant

Further $(s)$ and $(t)$ will be neglected.

The matrix transfer function from the master input impact $w$ to tracking error $z$ called the sensitivity function: 


$$
S=(I+G K)
$$

The transfer function from the master input signal to the output is called the additional sensitivity functions:

$$
T=G K(I+G K)^{-1}
$$

Note that the TFM of the closed-loop system $T$ establishes a connection between the output of the system and the input of the reference signal. This TF also determines like sensor noise (measurement noise) affects the system output. The sensitivity function $S$ describes the output as a function of the disturbance input. It also determines the response of the tracking error to the reference signal, i.e. $S$ is a transfer function by mistake. From the definitions of $S$ and $T$, it follows that

$$
S+T=\frac{I}{I+G K}+\frac{G K}{I+G K}=I
$$

Matrix transfer sensitivity the control function:

$$
R=K(I+G K)^{-1}
$$

Thus, $T$ is an additional sensitivity function, since $T$ in sum with $S$ is equal to one. Expression (4) is an important dependency, which imposes a limit on the achievable quality. $S$ is the sensitivity of the TF of a closed system to small perturbations in $G$.

The sensitivity function $S$ and the additional sensitivity function $T$ in combination with the weight functions $W_{S}, W_{R}$ and $W_{T}$ are widely used for quality assessment in the $H_{\infty}$-theory [6].

For example, the quality criterion can be expressed by the inequality:

$$
\left\|\mathrm{W}_{\mathrm{S}} \mathrm{S}\right\|_{\infty}<1
$$

In the future, we look for a regulator to minimize the rate $\left\|_{z_{1}}, z_{2}, z_{3}\right\|_{\infty}$.

At the same time, to parry disturbances, it is necessary to have an error $e$ in the low frequency range, and to ensure stability and suppression of high-frequency interference, it is desirable to have a small $y$ value in the high frequency range. To do this, an error $e$ in the low frequency range should be "weighed" with a greater weight than at high frequencies, i.e. the amplitude of the frequency response $W_{S}$ should decrease with increasing frequency ( $W_{S}$ is a low-pass filter). On the contrary, the amplitude of the frequency response $W_{T}$ should increase with increasing frequency $\left(W_{T}\right.$ - high pass filter). As for the frequency response of the $W_{R}$, it may be necessary to limit the power control, as well as a parameter that is adjustable to control the speed. Since the singular value $S(j \omega)$ determines the attenuation of the disturbances, the required attenuation of the disturbances can be given as

$$
\sigma_{1}(S(j \omega)) \leq\left|W_{S}^{-1}(j \omega)\right|
$$

Meaning the above, the boundaries for the other sensitivity functions are given in the form:

$$
\begin{aligned}
& \sigma_{1}(R(j \omega)) \leq\left|W_{R}^{-1}(j \omega)\right| \\
& \sigma_{1}(T(j \omega)) \leq\left|W_{T}^{-1}(j \omega)\right|
\end{aligned}
$$

In this case, condition must be satisfied

$$
\sigma_{1}\left(W_{S}^{-1}(j \omega)\right)+\sigma_{1}\left(W_{T}^{-1}(j \omega)\right)>1
$$

From the above it can be seen that the choice of weight functions is an ambiguous task, requiring for its decision sufficient developer experience, as well as the application of trial and error. The choice of these frequency characteristics also determines the ability to complete the solution of the $H_{\infty}$-control problem to the end, i.e. get the central controller.

After setting the weight matrices, the existing system expands so that it includes the equations of these matrices as additional phase coordinates. An extended system for regulator synthesis is an plant $P$.

The generalized plant $P$ (Fig. 3) has two inputs ( $w$ and $u$ ), two outputs ( $z$ and $y$ ) and can be divided into four TFM:

$$
P=\left[\begin{array}{c:c}
P_{11} & P_{12} \\
\hdashline P_{21} & P_{22}
\end{array}\right]=\left[\begin{array}{c|c}
W_{\mathbf{S}} & -W_{\mathbf{S}} G \\
0 & W_{\mathbf{R}} \\
0 & W_{\mathbf{T}} G \\
\hline I & -G
\end{array}\right]
$$

where $P_{\mathrm{ji}}-$ the TFM from $i$-th input to $j$-th output.

$F_{\mathrm{L}}(P, K)$ - is the TFM of the closed system from the disturbance input $w$ to the error output (controlled variable) $z, T_{\mathrm{zw}}$, which is obtained by the lower linear fractional transformation (LLFT) $[3,6]$ :

$$
\begin{gathered}
z=T_{\mathrm{zw}} w=F_{L}(P, K) w \\
T_{\mathrm{zw}}=F_{L}(P, K)=P_{11}+P_{12} K\left(I-P_{22} K\right)^{-1} P_{2 I}
\end{gathered}
$$

All system requirements for reducing disturbances and ensuring stability are reduced to a single requirement for the norm.

$$
\left\|T_{\mathrm{zw}}\right\|_{\infty} \leq 1
$$

where

$$
T_{\mathrm{zw}}=\left[\begin{array}{c}
W_{S} S \\
W_{R} R \\
W_{T} T
\end{array}\right]
$$


- the so-called cost function of the method of mixed sensitivity (mixed sensitivity).

Consequently, the task of $H_{\infty}$-optimization is the choice of such a regulator $K$, which would minimize the infinite norm $T_{\mathrm{zw}}$ or $\min \left\|T_{\mathrm{zw}}\right\|_{\infty}$. Moreover, the choice of the optimal controller $K$ is performed over the set of all regulators that have the property to make a closed system $T_{\mathrm{zw}}$ internally stable, i.e. over many stabilizing regulators. For a SISO system, the $H_{\infty}$-norm of the transfer function $G(s),\|G\|_{\infty}$ in a scalar expression is finite and equal to the maximum value of the amplitude-frequency characteristic $G(j \omega)$. Thus, the $H_{\infty}$-norm serves as a measure of the gain of the system. The $H_{\infty}$-norm of the TF is the output energy of the system when a single energy signal is applied to the input. If the output is an error, and the input is a disturbance, then by minimizing the $H_{\infty}$-norm of the TF, we minimize the error energy for the worst case of the input disturbance.

To create a generalized plant $P$, we used the following weight functions:

$$
W_{S}=\frac{s / M+\omega_{0}}{s+\omega_{0} A} ; \quad W_{R}=\text { const },
$$

where $A=0,001 \quad(-60 \mathrm{~dB})-$ the desired maximum permissible steady-state error in the steady-state mode; $\omega_{0}=200 \mathrm{~s}^{-1}-$ desired bandwidth; $M=4(12 \mathrm{~dB})-$ peak sensitivity.

In Fig. 5 shows the inversion of the weight sensitivity function $W_{S}^{-1}$.

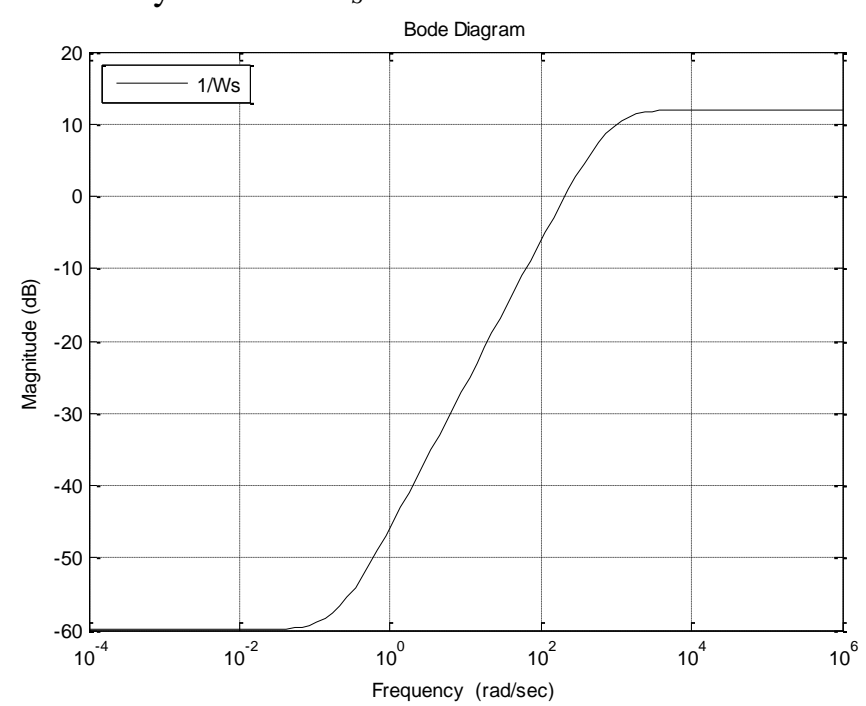

Fig. 5. Frequency characteristic of the sensitivity weight function inversion

Weight function of additional sensitivity

$$
W_{T}=\frac{s+\omega_{0} / M}{A s+\omega_{0}}
$$

- is not used.

The weight functions $W_{S}, W_{R}$, and $W_{T}$ "impose a penalty" on the error signal, control signal, and output signal, respectively. General recommendations for the selection of weight functions and the formation of a loop control (loopshaping) are set out in [6].

Weight functions are rational, stable, minimalphase transfer functions (that is, there are no poles or zeros in the right half-plane). Note that by purposefully changing the parameters of the weighting functions $A, \omega_{0}$ and $M$ (Fig. 5), the desired characteristics of the quality of the control system can be achieved, as shown by the authors in $[3,6]$.

Algorithms for the synthesis of the $H_{\infty}$-regulator using the "Two-Riccati Approach" are given in [1, $6]$.

The robust $H_{\infty}$-suboptimal speed controller SMPM was synthesized using the effective methods implemented in the Robust Control Toolbox expansion package, of MATLAB system, which allow the calculated algorithms to calculate the $H_{\infty^{-}}$ suboptimal controller that minimizes the $H_{\infty}$-norm of the closed system $\left\|T_{z \mathrm{w}}\right\|_{\infty}$. The synthesized robust speed controllers according to the $H_{\infty}$-norm criterion are 4th order controllers. The reached $H_{\infty}$-norm of the closed system, obtained during the iterative process, was 0.5308 .

In Fig. 6 shows the sensitivity function limited in amplitude by the weight sensitivity function

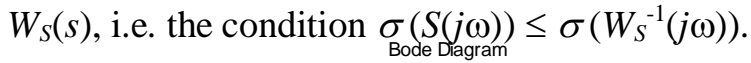

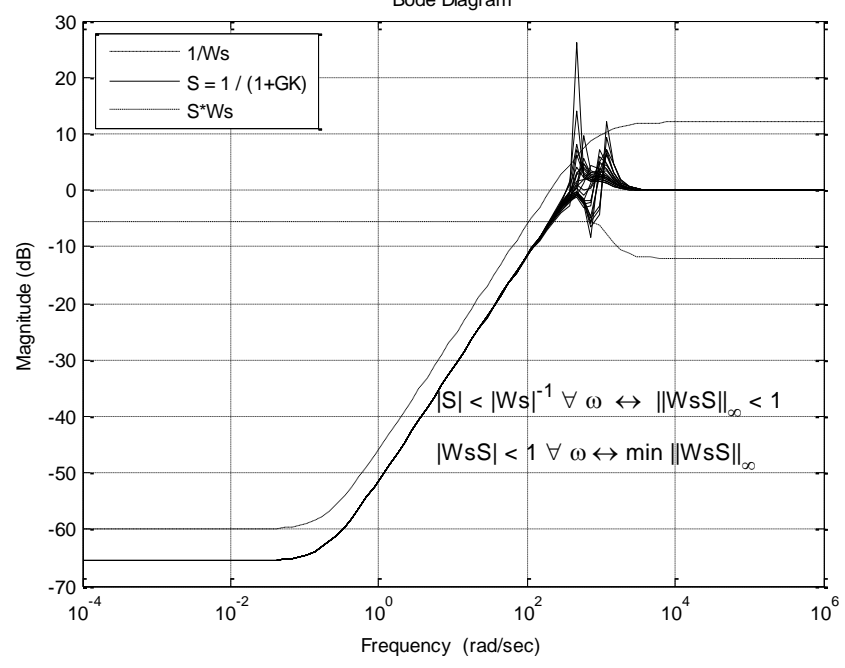

Fig. 6. Frequency characteristics of the sensitivity function $S$ and its product with weight function $W_{\mathrm{S}}$

This upper bound of the amplitude is inverted to obtain the weighting sensitivity function $W_{S}(s)$. So, if the sensitivity function $S(s)$ is multiplied by the weight function, then the amplitude $W_{\mathrm{S}} \mathrm{S}$ (s) will be less than or equal to one at the whole frequency. 
This example is called the "sensitivity weight problem" since the $H_{\infty}$-controller minimizes the maximum $W_{S} S$ value at the entire frequency as shown in Fig. 6.

Synthesized by means of the Robust Control Toolbox, the $H_{\infty}$-suboptimal speed controller is represented by an equation in the state space given in the table 1 .

Table 1 $H_{\infty}$-suboptimal speed controller in the state space

\begin{tabular}{|c|c|c|c|c|c|c|}
\hline \multicolumn{5}{|c|}{$a=$} & \multicolumn{2}{|l|}{$\mathrm{b}=$} \\
\hline & $\mathrm{x} 1$ & $x 2$ & $x^{3}$ & $\times 4$ & & u1 \\
\hline$x 1$ & -0.2006 & 11.7 & -0.06689 & -0.9372 & $x 1$ & 3.346 \\
\hline$x^{2}$ & 11.7 & $-2.175 e+04$ & 5435 & 3280 & $x 2$ & -98.31 \\
\hline x3 & 0.06689 & -5435 & -0.7222 & -21.65 & $\times 3$ & -0.5535 \\
\hline$\times 4$ & -0.9372 & 3280 & 21.65 & -2502 & $\times 4$ & 7.819 \\
\hline $\mathrm{C}=$ & & & & & $\mathrm{d}=$ & \\
\hline & $x 1$ & $x 2$ & $\times 3$ & $\times 4$ & & u1 \\
\hline$y 1$ & 3.346 & $-98 \cdot 31$ & 0.5535 & 7.819 & y1 & 0 \\
\hline
\end{tabular}

In Fig. 7 shows the results of the simulation of electric drive system with a $H_{\infty}$-regulator of the speed of testing a closed ACS of a given trajectory while simultaneously changing the moment of inertia $J$ and the stator winding resistance $R_{S}$ in a 4 times.
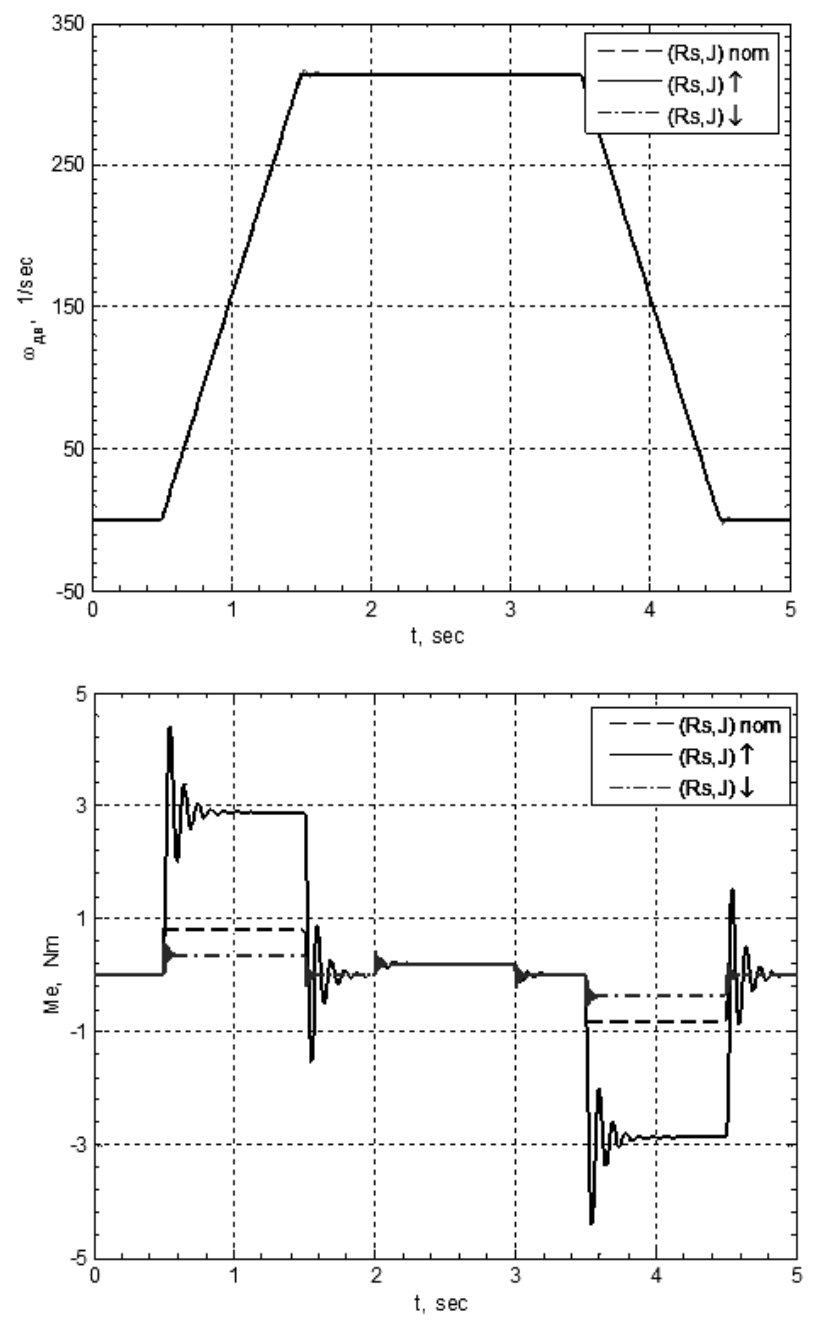

Fig. 7. Simulation results of a robust control system with a simultaneous change $J$ and $R_{\mathrm{s}} 4$ times the nominal parameters of the control plant
The efficiency of the robust system is confirmed by experimental studies of the permanentmagnet synchronous motors 1FT6044-1AF71 type and its power supply from the frequency converter SINAMICS S120 [8, 9].

\section{Conclusions}

The possibility of using robust control systems of $H_{\infty}$-controller of the speed of a synchronous electric drive to stabilize and control the speed in the context of incomplete information about the plant and taking into account its uncertainties with high quality indicators.

Synthesized $H_{\infty^{-}}$controller provides the control system with robust quality characteristics (reduces the sensitivity of the system to changes in plant parameters to the required level) and the specified accuracy of speed maintenance.

\section{References}

1. Doyle, J. C., Glover, K., Khargonekar, P. P., Francis, B. A. (1989), "State-space solutions to standard $\mathrm{H}_{2}$ and $\mathrm{H}_{\infty}$-control problems", IEEE Trans. Automat. Control, 34(8), pp. 831-847.

2. Egupov, I. P. (2002) "Methods of robust, neurofuzzy and adaptive control" [Metody robastnogo, neyro-nechetkogo i adaptivnogo upravleniya], Moscow: MSTU named after NE Bauman, 744 p.

3. Polilov, E. V., Rudnev, Ye. S., Skorik, S. P. (2010) "Synthesis of robust control algorithms for synchronous electric motor using $\mathrm{H}_{\infty}$-theory methods" [Sintez algoritmov robastnogo upravleniya sinkhronnym elektrodvigatelem metodami $\mathrm{H}_{\infty}$ teorii], Herald of the Mikhailo Ostrogradsky Kremenchuk State Power University. Kremenchuk: KDU, vol. 3, 4(63), pp. 15-20.

4. Chee-Mun Ong (1997) "Dynamic Simulation of Electric Machinery Using Matlab/Simulink", Prentice Hall, Englewood Cliffs, NJ, $626 \mathrm{p}$.

5. Kim Mun-Soo, Dall-Sup Song, Yong-Kil Lee, Tae-Hyun Won (2001) "A robust control of permanent magnet synchronous motor using load torque estimation," IEEE International Symposium on Industrial Electronics, vol. 2, pp. 1157-1162.

6. Polilov, E. V., Rudnev, Ye. S., Skorik, S. P. (2012) "Robust control of synchronous electric drive" [Robastnoye upravleniye sinkhronnym elektroprivodom], Monograph, Alchevsk: DonSTU, $253 \mathrm{p}$.

7. Rudnev, Ye. S., Morozov, D. I. (2016) "Linearized mathematical model of a permanent 
magnet synchronous motor as a control object" [Linearizovannaya matematicheskaya model sinkhronnogo dvigatelya s postoyannymi magnitami kak obyekta upravleniya] Collection of scientific papers of Donbass State Technical University. Lysychansk: DonSTU, 1(45), pp. 88-93.

8. Rudnev, Ye. S. (2012) "Practical implementation and study of robust algorithms for control of synchronous electric drive" [Prakticheskaya realizatsiya i issledovaniye robastnykh algoritmov upravleniya sinkhronnym elektroprivodom], Electromechanical and energysaving systems. Kremenchuk: KrNU, 3(19), pp. 102-107.

9. Polilov, E. V., Batrak, A. M., Rudnev, Ye. S., Skorik, S. P., Gorelov, P. V. (2011) "The research stand for approbation of control algorithms for complex electromechanical systems" [Issledovatelskiy stend dlya aprobatsii algoritmov upravleniya slozhnymi elektromekhanicheskimi sistemami], Electrotechnical and computer systems. Kiev: Technique, 3(79), pp. 481-487.

\title{
Н INF РОБАСТНЕ КЕРУВАННЯ СИНХРОННИМИ ДВИГУНАМИ З ПОСТІЙНИМИ МАГНІТАМИ: СТІЙКІСТЬ І ЯКІСТЬ
}

\author{
Є. С. Руднєв, Д. І. Морозов, В. Ю. Грицюк \\ Східноукраӥнський національний університет імені Володимира Даля
}

\begin{abstract}
Анотація. Однією з основних проблем сучасної теорї керування є керування динамічними об'єктами в умовах невизначеності. В останні десятиліття отримує розвиток підхід, коли при наявності невизначеності виникає завдання керування не єдиним об'єктом, а сімейством об'єктів, щьо належать до заданої множини. Інтерес до синтезу робастних регуляторів пов'язаний $з$ потребами в зниженні необхідного обсягу апріорної інформаџії про об'єкти керування, прагненням до універсальності керуючих систем і скорочення витрат на їх наладку. Синтезований робастний

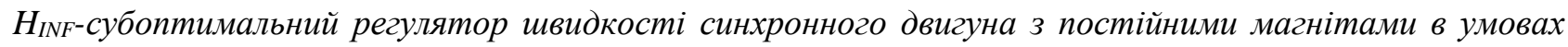
неповної інформації про об'єкт з урахуванням його невизначеностей. Робастний регулятор

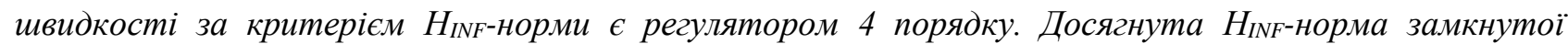

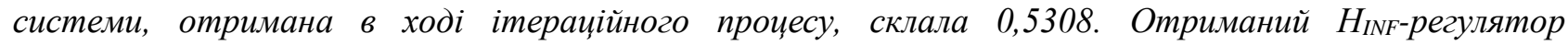
забезпечує системі керування робастні характеристики якості (знижує чутливість системи до змін параметрів об'єкта до необхідного рівня) $і$ задану точність підтримки швидкості. Вибір вагових функиій є неоднозначним завданням, що вимагає для свого рімення достатнього досвіду розробника, а також застосування методу проб $і$ помилок. При цілеспрямованій зміні параметрів вагових функиій можна досягти бажаних характеристик якості системи керування. Ефективність робастної системи підтверджена експериментальними дослідженнями синхронного двигуна 3 постійними магнітами і живленні його від перетворювача частоти SINAMICS S120. Показано, що використання робастного регулятора дозволяє істотно зменшити вплив параметричних $i$ зовнішніх збурень на якість регулювання. Отримано результати моделювання в пакеті Matlab/Simulink.
\end{abstract}

Ключові слова: синхронний електропривод, робастне керування, невизначеність, чутливість, моделювання.

\section{Н С ПОСТОЯННЫМИ МАГНИТАМИ: УСТОЙЧИВОСТЬ И КАЧЕСТВО}

\author{
Е. С. Руднев, Д. И. Морозов, В. Ю. Грицюк \\ Восточноукраинский начиональный университет имени Владимира Даля
}

\begin{abstract}
Аннотация. Рассмотрена инженерная методика синтеза робастной системы управления электроприводом переменного тока на базе синхронного электродвигателя с возбуждением от

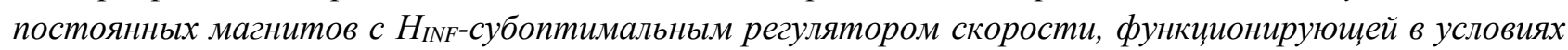
неполной информации об объекте и с учетом его структурных неопределенностей. Показано, что
\end{abstract}


использование робастного регулятора позволяет существенно уменьшить влияние параметрических и внешних возмущений на качество регулирования. Получены результаты моделирования в пакете Matlab/Simulink.

Ключевые слова: синхронный электропривод, робастное управление, неопределенность, чувствительность, моделирование.

Received 15.02.2019

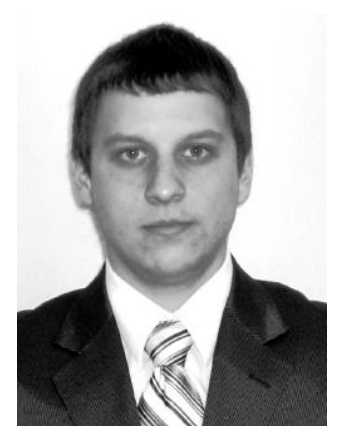

Yevgeny Rudnev, Ph.D., Associate Professor of the department of electrical engineering, Volodymyr Dahl East Ukrainian National University, Central ave., 59-a, Severodonetsk, Ukraine, E-mail: rudnevevgen@ gmail.com, tel. +38-050-682-38-58

Руднєв Євген Сергійович, кандидат технічних наук, доцент, доцент кафедри електричної інженерії Східноукраїнського національного університету імені Володимира Даля. Просп. Центральний, 59-а, м. Сєвєродонецьк, Україна, E-mail: rudnevevgen@ gmail.com, тел. +38-050-682-38-58

ORCID ID: 0000-0002-4236-8407

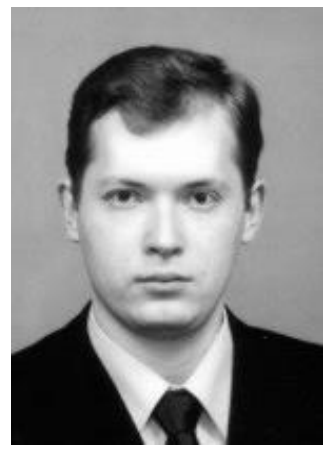

Dmitry Morozov, Ph.D., Head of the department of electrical engineering, Volodymyr Dahl East Ukrainian National University, Central ave., 59-a, Severodonetsk, Ukraine, E-mail: dimorozov3@gmail.com, tel. +38-095-849-11-73

Морозов Дмитро Іванович, кандидат технічних наук, доцент, завідуючий кафедри електричної інженерії Східноукраїнського національного університету імені Володимира Даля. Просп. Центральний, 59-а, м. Сєвєродонецьк, Україна, E-mail: dimorozov3@gmail.com, тел. +38-095-849-11-73

ORCID ID: 0000-0003-1773-7140



Volodymyr Gritsyuk, Ph.D., Associate Professor of the department of electrical engineering, Volodymyr Dahl East Ukrainian National University, Central ave., 59-a, Severodonetsk, Ukraine, E-mail: gritsyukvy@gmail.com, tel. +38-099-948-54-33

Грицюк Володимир Юрійович, кандидат технічних наук, доцент кафедри електричної інженерії Східноукраїнського національного університету імені Володимира Даля. Просп. Центральний, 59-а, м. Сєвєродонецьк, Україна, E-mail: gritsyukvy@gmail.com, тел. +38-099-948-54-33

ORCID ID: 0000-0003-0156-7589 